Brit. J. industr. Med., 1963, 20, 264.

\title{
ALUMINIUM PNEUMOCONIOSIS I. IN VITRO COMPARISON OF STAMPED ALUMINIUM POWDERS CONTAINING DIFFERENT LUBRICATING AGENTS AND A GRANULAR ALUMINIUM POWDER
}

BY

B. CORRIN

From the Department of Pathology, University of Manchester

(RECEIVED FOR PUBLICATION NOVEMBER 22, 1962)

The discrepancy in previous reports of the action of aluminium on the lung may be explained by differences between stamped and granular aluminium powders. A stamped powder of the variety causing pulmonary fibrosis showed a brisk reaction with water, but a granular powder was unreactive. This difference is primarily due to the granular particles being covered by inert aluminium oxide, the formation of which is partially prevented in the stamping process by stearine and mineral oil. The reactivity of the flake-like stamped particles is also dependent on their large surface area per unit volume.

The appearance of aluminium pneumoconiosis in Britain is explained by the introduction of mineral oil into the stamping industry for, in contrast to stearine, mineral oil permits the powder to react with water. The lung damage is believed to be caused by a soluble form of aluminium.

Aluminium holds a paradoxical position in relation to pulmonary disease. Whereas inhalations of the metal have been used without ill effect in the treatment of silicosis, rapidly progressive and often fatal pulmonary fibrosis has been recorded following exposure to aluminium dust, notably in Germany (Goralewski, 1947). Furthermore, the recent and sudden appearance of this severe and characteristic disease in Britain (Mitchell, Manning, Molyneux, and Lane, 1961; Jordan, 1961) is surprising because the powder concerned has been in production here for many years. This paper attempts to elucidate these problems.

\section{Different Types of Aluminium Powder}

Aluminium powder may be produced in two forms, one consisting of granular particles and the other of thin flake-like particles. The granular powder is produced from molten aluminium but the flaked form is made by stamping the cold metal (Edwards and Wray, 1955). Mitchell's patients were employed at a stamp mill producing a particularly fine aluminium powder known as Pyro, and Jordan's patient handled this powder in a firework factory. Ventilation is restricted at the stamping mill to lessen the risk of explosion, and the dust cannot be damped with water as this releases hydrogen.

This study started with an investigation of the reaction between Pyro and water. A sample of the Pyro powder in current production was obtained. This contained small amounts of stearine and spindle oil and had the following particle size distribution: over $5 \mu, 3 \% ; 1$ to $5 \mu, 47 \%$; below $1 \mu, 50 \%$. Other particulars of this powder are given by Mitchell et al. (1961). Varying amounts of the powder, ranging from 0.5 to $6 \mathrm{~g}$., were each shaken well with $100 \mathrm{ml}$. of distilled water. After 12 hours, dust particles attached to small gas bubbles were seen rising to the surface while other particles which had released their bubbles were slowly sinking. After 48 hours, light grey foam, the lower layers of which had a gel-like consistence, protruded from some of the containers. Much of the dust had settled to the bottom and the water was white and opalescent. The dried foam consisted microscopically of dust particles surrounded by white amorphous material. A little of the dried foam was shaken with 
an excess of water. The water at first became cloudy but soon white floccules settled out together with the dust particles, leaving a clear supernatant. After three days the opalescent solution beneath the foam also formed large white floccules and in one case an opalescent gel formed. The gas evolved in the reaction burnt with a light blue flame, or if mixed with air exploded on ignition. It is concluded that Pyro powder reacts with water to produce aluminium hydroxide and hydrogen.

A granular form of aluminium powder was obtained for comparison. This was $99.5 \%$ pure and had the following particle size distribution: 1 to $5 \mu$, $11 \%$; 5 to $10 \mu, 17 \%$; over $10 \mu, 72 \%$. On mixing this powder with water no reaction occurred over four weeks.

\section{Different Types of Lubricant}

The first of Mitchell's patients started work at the stamping mill in 1952, and the management were asked if any change had been made in the manufacturing process at that date. A minor change in the method of Pyro production was then recalled. Small amounts of stearine and spindle oil are added to the stamping process to assist separation of the particles. Until 1952 no lubricant other than stearine had been used, but spindle oil was then substituted for half the amount of stearine added to the Pyro powder. This corresponds to the conditions in war-time Germany where stearine was unobtainable and Ceresine had to be used. Ceresine is a waxy higher hydrocarbon of mineral origin, a non-polar substance which in this respect is more akin to the spindle oil than to the animal fatty acid stearine.

Three Pyro powders made with different lubricating agents were therefore obtained for comparison. One was the current product made with both stearine and spindle oil. The other two were specially made at the factory, one using oil but no stearine and the other using stearine but no oil, the latter corresponding to the powder produced before 1952 .

The three powders were identical in physical appearance but differences between the stearinecontaining and the oil-containing powders were noted when they were mixed with water. Whereas the one containing oil could be suspended fairly easily, that containing stearine required vigorous prolonged shaking. On discarding these suspensions, the oil-containing powder flowed away as a black suspension but the stearine-containing powder spread out in a bright silvery film. This phenomenon is well known in connexion with aluminium paint, in which it is much more marked and is called "leafing". It results from the particles rising to the surface and spreading out with their edges overlapping, a property which is partly responsible for the efficiency of the paint and which is a function of the stearine content (Edwards and Wray, 1955). Extra amounts of stearine are added to the paint powders for this purpose.

The reaction of the powders with water was studied quantitatively after they had been well suspended by vigorous shaking. Known weights, approximately $40 \mathrm{mg}$., of each powder were shaken well with $100 \mathrm{ml}$. of distilled water and the hydrogen evolved was collected in $50 \mathrm{ml}$. burettes. The suspensions were immersed in a $37^{\circ} \mathrm{C}$. water bath and the volumes of hydrogen evolved were measured at intervals over three days. After this time the supernatant solution was decanted and the reactions completed with concentrated hydrochloric acid. The amounts of hydrogen evolved with water were calculated as percentages of the total hydrogen evolved with both water and acid, all volumes being first corrected to N.T.P. This gave the amount of aluminium reacting with water as a percentage of that present.

The three powders showed marked differences in their reactions (Table). After 72 hours no reaction had occurred with the stearine-coated powder, but $89 \%$ of the metallic aluminium in the oil-containing powder had reacted with water. The powder prepared with both stearine and oil occupied an intermediate position, $56 \%$ of the metal reacting with water. Almost identical results were obtained when physiological saline was used instead of water.

\section{Discussion}

Aluminium has a strong chemical affinity for water but usually appears inactive because atmospheric oxidation produces a surface coat of inert aluminium oxide which prevents both further atmospheric oxida-

TABLE

MEtAllic ALUminium ReACTING WITH WATER AS A PERCENTAGE OF THAT PRESENT IN THE POWDERS

\begin{tabular}{|c|c|c|c|c|c|c|c|c|}
\hline & \multicolumn{8}{|c|}{ Hours } \\
\hline & 3 & 6 & 9 & 24 & 30 & 48 & 54 & 72 \\
\hline $\begin{array}{l}\text { Stearine-containing powder } \\
\text { Stearine- and oil-containing powder } \\
\text { Oil-containing powder }\end{array}$ & $\begin{array}{l}\mathbf{0} \\
\mathbf{0} \\
\mathbf{1}\end{array}$ & $\begin{array}{l}0 \\
2 \\
5\end{array}$ & $\begin{array}{c}0 \\
6 \\
18\end{array}$ & $\begin{array}{c}0 \\
48 \\
71\end{array}$ & $\begin{array}{c}\mathbf{0} \\
52 \\
77\end{array}$ & $\begin{array}{c}0 \\
55 \\
85\end{array}$ & $\begin{array}{c}0 \\
56 \\
86\end{array}$ & $\begin{array}{l}0 \\
56 \\
80\end{array}$ \\
\hline
\end{tabular}


tion and attack by water. The reaction of Pyro with water suggests either destruction of this coat or the prevention of its formation.

Impurities in the powder, especially mercury, could impair the protective action of surface alumina, and samples of Pyro were therefore examined by spectrographic analysis. This showed about $0.5 \%$ silicon and about $0.1 \%$ each of copper, magnesium, manganese, and iron; but mercury, beryllium, arsenic, antimony, bismuth, nickel, tin, and lead could not be detected. The trace elements present are common to both stearine- and oil-containing Pyro and cannot account for the difference between these two powders.

Atmospheric oxidation could be prevented during the stamping process by stearine and spindle oil. Stearine also prevents attack by water but the oil appears to be washed away, exposing metallic aluminium to water. Aluminium hydroxide, rather than oxide, is then formed, and this allows the reaction to continue. Stearine may combine with the metal to form aluminium stearate, but the oil consists of non-polar cyclic hydrocarbons and has nothing capable of forming a bond with aluminium. No lubricating agents are present in granular powders.

The dusts will presumably react in pulmonary tissue fluid as they have in these experiments, and aluminium will only be released from the oil-coated powder. If the pulmonary fibrosis is caused by any soluble product of aluminium, the substitution of a mineral product for stearine would provide an explanation for the sudden appearance of the disease in Britain and, as suggested by Jäger and Jäger (1941), in war-time Germany. These workers suggested chemical rather than mechanical damage to the lung tissue, and the present experiments, confirming those of Jäger and Jäger, support this idea. This solubility theory is also supported by Nagelschmidt's (1960) suggestion that beryllium, aluminium, bauxite fume, and asbestos may be separated from quartz, coal, haematite, talc, kaolin, and other dusts: those in the first group are relatively soluble, cause a diffuse pulmonary fibrosis, and are only found in the lung in small amounts on chemical analysis, whereas the other dusts are relatively insoluble and cause a nodular fibrosis, the severity of which matches the amount of dust found in the lung. In aluminium pneumoconiosis, Nagelschmidt quotes Mitchell's (1959) figures to demonstrate the paucity of aluminium $(0.03 \%$ of the dried lung) in a case showing extensive fibrosis. Presumably much of the aluminium inhaled dissolves and is washed away.

The reaction permitted by the spindle oil will be magnified by the large surface area per unit volume of the flake-like Pyro particles. Granular particles are roughly spherical and have a low surface area per unit volume. It seems unlikely that this difference in surface area by itself could account for the difference in reaction between the two types of powder since, however large the surface of the stamped powder, it would be inactive if totally covered by inert alumina. The difference in surface areas will, however, accentuate the effect of the lubricating agents; and the combination of a surface coat of spindle oil and a large surface area probably accounts for the marked reaction of oil-containing Pyro with water.

The differences demonstrated between granular powder, stamped powder made with stearine, and stamped powder made with oil may explain the anomalous position aluminium dust holds in relation to pulmonary disease, especially if aluminium pneumoconiosis is related to the solubility of the powder. This disease occurs only in connexion with stamped aluminium whereas the powders used in the treatment of silicosis are similar to the granular powders. Those used by Denny, Robson, and Irwin (1939) and by Crombie, Blaisdell, and MacPherson (1944) were produced from aluminium pellets in a revolving drum without the addition of a lubricant. The present McIntyre foundation product contains no lubricant (Irwin, personal communication, 1963) and consists largely of aluminium oxide (Newkirk, Hannon, and Campbell, 1956). The dust which Sutherland, Meiklejohn, and Price (1937) found to be harmless was not metallic aluminium but its oxide, and in Hunter's investigation of aluminium propeller grinders (Hunter, Milton, Perry, and Thompson, 1944), in which no evidence of pulmonary disease was found, the respirable dust came from the aluminium oxide abrasive and not from the aluminium propellers. Other negative findings (Koelsch and Lederer, 1933; Ehrismann, 1939; Crombie et al., 1944) concern stamped aluminium powder, but in these cases the powder was that used to make aluminium paint. This usually has a large particle size, most particles being outside the respirable range, and a relatively high content of lubricant which is entirely stearine.

It can be seen that the apparently contradictory reports on the effects of aluminium actually relate to powders which, although basically composed of aluminium, differ in several important respects. Some harmless powders consist entirely of aluminium oxide; others contain metallic aluminium but have an inert coat of aluminium oxide and a relatively small surface area, or, if of the stamped variety, are outside the respirable range and have been made using stearine as the sole lubricant. The powders concerned with pulmonary fibrosis are always of the stamped variety and have a relatively large surface area, part of which consists of metallic aluminium 
covered only by a lubricating agent which is generally permeable to water.

The lubricant in the fibrogenic powders has generally been a mineral wax or oil, but recently McLaughlin, Kazantzis, King, Teare, Porter, and Owen (1962) have reported pulmonary fibrosis in an aluminium stamper handling stearine-containing powders only. The difference between stearine and mineral lubricants may therefore be relative rather than absolute. It is interesting that McLaughlin et al. found large quantities of dust in the lung, whereas there was little dust in the cases described by Mitchell and his colleagues. This difference would be expected from the solubilities of stearine- and oil-containing powders.

I am grateful to Professor R. E. Lane and to Mr. M. Molyneux of the Department of Occupational Health for helpful advice in the preparation of this paper, and to
Mr. R. A. J. Shelton of the Department of Metallurgy for the spectrographic analysis.

\section{REFERENCES}

Crombie, D. W., Blaisdell, J. L., and MacPherson, G. (1944). Canad.

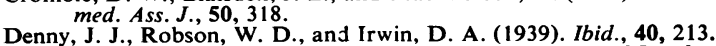

Eenny, J. J., Robson, W. D., and Irwin, D. A. (1939). Ibid., 40, 3rd ed. Reinhold, New York.

Ehrismann, O. (1939). Z. Hyg. Infekt.-Kr., 122, 166

Goralewski, G. (1947). $Z$ ges. inn. Med., 2, 665 .

Hunter, D., Milton, R., Perry, K. M. A., and Thompson, D. R. (1944) Brit. J. industr. Med., 1, is9.

Jäger, R., and Jäger, F. (1941). Arch. Gewerbepath. Gewerbehyg., 11, 117.

Jordan J W (1961) Brit J industr. Med , 18, 21.

Koelsch, F., and Lederer, E. (1933). Arch. Gewerbepath. Gewerbehyg., 5,108 .

McLaughlin, A. I. G., Kazantzis, G., King, E., Teare, D., Porter, R. J., and Owen, R. (1962). Brit. J. industr. Med., 19, 253.

Mitchell, J.'(1959). Ibid., 16, 123 .

, Manning, G. B., Molyneux, M., and Lane, R. E. (1961). Ibid., $18,10$.

Nagelschmidt, G. (1960). Ibid., 17, 247.

Newkirk, T. E., Hannon, J. W.' G., and Campbell, A. D. (1956). Proc. McIntyre Research Found., 8,1

Sutherland, C. L., Meiklejohn, A., and Price, F. N. R. (1937). J. industr. Hyg., 19, 312. 